\title{
UNITED WE STAND - DIVIDED WE FALL: ASSESSING THE POTENTIAL OF THE EU AND ITS CITIZENS TO CONFRONT THE CORONAVIRUS PANDEMIC AS A CHANCE TO REAFFIRM THE EUROPEAN IDENTITY
}

\author{
Jeronim Dorotić, PhD, Postdoctoral Researcher \\ Catholic University of Croatia \\ Ilica 242, Zagreb, Croatia \\ jeronim.dorotic@unicath.hr
}

\begin{abstract}
The main aim of this paper is to assess the potential of the EU and its citizens to face the Coronavirus pandemic as a chance to reaffirm the European identity. This paper consists of three complementary parts. In the first part conceptualization of the European identity is presented according to the views of the EU institutions and relevant authors with purpose to signify its importance for further development of the EU project. In the second part the extent to which the EU citizens are currently affiliated with the European Union is assessed, especially with regard to the response of the EU to confront the pandemic (i.e. by relying on recent Eurobarometer surveys). Third and the central part of this paper is focused on providing the review and analysis of relevant solidarity actions directed to confront Coronavirus crisis by the EU institutions and representative CSOs active specifically at the EU level in the field of promoting European citizenship. The key findings of this inquiry indicate that analysed initiatives contain solidarity dimension, and therefore, have potential to reaffirm the European identity, that is, to enhance cohesion and unity among the EU citizens.
\end{abstract}

Key words: Coronavirus pandemic, EU citizenship, European identity, European Union, civil society organizations (CSOs).

\section{INTRODUCTION}

Considering that overall approaches taken by the EU to confront the Coronavirus pandemic will either have beneficial or detrimental impact on the future of the European integration process, the main aim of this paper is to assess the potential of the $\mathrm{EU}$ and its citizens to face this crisis as a chance to reaffirm the European identity. 
In other words, by focusing on the responses (i.e. selected policies and initiatives) directed to meet the challenges of the Coronavirus crisis by the EU institutions and CSOs active in the field of promoting European citizenship, this paper shall signify that analyzed initiatives contain solidarity dimension, and for that reason have potential to enhance cohesion and unity among the EU citizens which may positively affect the European integration process in and after the pandemic. Nevertheless, to reach relevant findings it will be necessary to apply qualitative methodology to this inquiry, which refers to the content analysis of relevant primary and secondary sources.

Moreover, besides introduction and conclusion, this paper will consist of three complementary parts. Therefore, in the first part it will be needed to conceptualize the European identity according to the views of the EU institutions (i.e. by referring to the EU's legislation and documents) and relevant authors (i.e. Risse, Delanty \& Rumford, Castells and Shore) with purpose to signify its importance for further development of the EU project. Likewise, in the second part it will be necessary to assess the extent to which the EU citizens are currently affiliated with the European Union, especially with regard to the response of the EU to confront the pandemic (i.e. by relying on recent Eurobarometer surveys). Third and the central part of this paper will be focused on providing the review and analysis of relevant solidarity actions directed to confront Coronavirus crisis by the EU institutions and representative CSOs active specifically at the EU level in the field of promoting European citizenship (i.e. Civil Society Europe, European Citizen Action Service and European Civic Forum). Final remarks regarding the findings of this inquiry will be provided in the conclusion. Lastly, the significance of this topic springs from the view that despite of evident detrimental effects, this crisis can also be perceived as an opportunity which has potential to increase solidarity and cooperation across the EU Member States.

\section{CONCEPTUALIZING EUROPEAN IDENTITY ACCORDING TO THE VIEWS OF THE EU INSTITUTIONS AND RELEVANT AUTHORS $^{1}$}

\subsection{Overview of the evolving approaches aimed at bringing Union closer to its citizens by the $\mathrm{EU}$ institutions}

In order to portray how the EU institutions view European identity it is needed to concisely refer to selected EU documents which in general indicate for what rea-

It is important to notify that certain insights regarding the conceptualization of the European identity derive from the author's Doctoral thesis: Dorotić, J., Krajobrazne politike i njihova uloga u izgradnji identiteta EU, (Landscape Policies and Their Role in Building the EU Identity) Doctoral thesis, Sveučilište Josipa Jurja Strossmayera u Osijeku, 2019. 
sons, by which means and in what forms are EU policy-makers aiming at bringing European Union closer to its citizens. Therefore, by examining the evolving approaches of the EU institutions aimed at rising affiliation of European citizens towards the Union it appears that, in general, initial intention expressed in the Treaty of Rome (1958) "to lay the foundations of an ever-closer union among the peoples of Europe" 2 was eventually articulated in creation of European citizenship - a concept which fosters identification with the EU and therefore closely corresponds with the notion of European identity. Specifically, this is evident by chronological overview of several EU documents which are reveling evolving ideas and mechanisms of the EU institutions directed towards making European citizens aware of their association with the EU. In general these documents encompass the Declaration on European Identity (1973), ${ }^{3}$ then the Solemn Declaration on European Union (1983), ${ }^{4}$ following the reports on a People's Europe initiative $(1985)^{5}$ and the Treaty on European Union (TEU, 1993) ${ }^{6}$ - by which European citizenship was introduced within the primary EU legislation. Likewise, following the subsequent amendment of the TEU and the Treaty on the Functioning of the European Union (TFEU, 1958) by the Treaty of Lisbon (LU, 2009) ${ }^{8}$, the Charter of Fundamental Rights of the European Union (CFREU, 2000) ${ }^{9}$ was incorporated within the primary EU legal framework which reconfirmed previously indicated specifications regarding the rights of the EU citizens.

More precisely, due to growing common stands of the nine Member States of the European Communities in the global context, in 1973 their leaders explicitly addressed the importance and defined the contours of European identity "in a light of the progress made in the construction of a United Europe". ${ }^{10}$ Accordingly, authors of the Declaration on European Identity were already at that time aware of the fact that belonging of the Member States to common heritage, values

2 Treaty establishing the European Economic Community. Rome, 25 March 1957, preamble, p. 2.

3 Declaration on European Identity, (Copenhagen, 14 December 1973), Bulletin of the European Communities. December 1973, No 12 (Declaration on European Identity).

4 Solemn Declaration on European Union, (Stuttgart, 19 June 1983), Bulletin of the European Communities, No. 6/1983 (Solemn Declaration on European Union).

5 A People's Europe: Reports from the ad hoc Committee, Bulletin of the European Communities, Supplement 7/85. Luxemburg: Office for Official Publications of the European Communities, 1985 (A People's Europe).

6 Treaty on European Union (Consolidated Version 2016), OJ C 202, 7.6.2016.

7 Treaty on the Functioning of the European Union (Consolidated version 2016), OJ C 202, 7.6.2016.

8 Treaty of Lisbon amending the Treaty on European Union and the Treaty establishing the European Community, signed at Lisbon, 13 December 2007, OJ C 306, 17.12.2007.

9 Charter of Fundamental Rights of the European Union (2016), OJ C 202, 7.6.2016. The Charter was proclaimed in 2000, but became legally binding in 2009 by the Treaty of Lisbon.

10 Declaration on European Identity, op. cit., note 3, p. 48. 
and institutions in the global context has great significance for further European integration process, which should eventually lead towards the "United Europe". Specifically, by this document European identity was framed within the three subsequent areas: firstly, in the area of recognizing commonalities and the current state of unity between the Member States; secondly, in the area of asserting contemporary common position of the Community in international affairs; and thirdly, in the area which considers the dynamic nature of European unification process. ${ }^{11}$ Apart from the first two areas of the document it is significant to refer directly to the last one, since within it notable role of European identity was specified in the context of articulating common foreign policy, which would eventually contribute to successful European integration process. In this regard the following is stated in the same document: "The European Identity will evolve as a function of the dynamic construction of a United Europe. In their external relations, the Nine propose progressively to undertake the definition of their identity in relation to other countries or groups of countries." 12

Furthermore, ten years later the significance of European identity for the European integration process was additionally signified in 1983 through the Solemn Declaration on European Union (which preceded the Single European Act and the Maastricht Treaty). Namely, among the main objectives of this document, it has been clarified that leaders of the Member States "on the basis of an awareness of a common destiny and the wish to affirm the European identity, confirm their commitment to progress towards an ever closer union among the peoples and Member States of the European Community." 13 Moreover, in the same document specific connection is made between common cultural heritage and European identity. In other words, among other objectives of the document which are all aiming "to consolidate the progress already made towards European Union", the intention is also expressed for "closer cooperation on cultural matters, in order to affirm the awareness of common cultural heritage as an element in the European identity." ${ }^{14}$

However, already in 1984 the European Council has appointed an ad hoc Committee chaired by Pietro Adonnino to coordinate a People's Europe initiative in order to articulate specific mechanisms and areas of action which "should respond to the expectations of the people of Europe by adopting measures to strengthen and promote its identity and its image both for its citizens and for the rest of

\footnotetext{
$11 \quad$ Ibid., p. 48.

$12 \quad$ Ibid., p. 54.

13 Solemn Declaration on European Union, op. cit., note 4, p. 25.

14 Ibid., p. 25.
} 
the world." 15 In this regard, it is important to signify several measures initiated within the subsequent reports of the mentioned Committee during 1985, which are specifically aiming at bringing Union closer to its citizens in the following fields: the special rights of citizens (e.g. participation in the political process in the Community), culture and communication (e.g. encouragement of European audiovisual co-productions, access to museums and cultural events), youth, education, exchanges and sports (e.g. language teaching, exchanges between schools, promotion of the European image in education, endorsing $9^{\text {th }}$ of May as Europe Day), twinning (i.e. between towns and cities), and strengthening of the Community's image and identity (e.g. introduction of Community's symbols such as a blue flag with 12 golden stars and anthem 'Ode to Joy'). ${ }^{16}$

Consequently, by the Treaty on European Union in 1993 the European citizenship was introduced within the primary legal framework of the Union as a concept which directly associates European citizens with the EU, and therefore closely reflects and fosters the official EU stands regarding the European identity. In this regard, by referring to consolidated versions of TEU and TFEU within the Lisbon Treaty (2009) it is important to denote that already within the preamble of TEU it is clarified that leaders of the Member States are "resolved to establish a citizenship common to nationals of their countries" as well as it is specifically stated that European identity shall be reinforced in the context of implementation of common foreign and security policy and subsequent common defence policy. ${ }^{17}$ However, precise content of European citizenship, which in general refers to specific rights and duties, is articulated between Articles 9 and 12 TEU, ${ }^{18}$ as well as between Articles 18 and 25 TFEU $^{19}$.

In this regard, and due to limited framework of this paper, it is adequate just to extract that within the Article 9 TEU it is explicitly stated that all nationals of the Member States hold the EU citizenship which "shall be additional to and not replace national citizenship." ${ }^{20}$ Also, by referring to the Article 20 TFEU it is possible to denote that EU citizenship comprises of the rights and duties such as the right to move and reside within the EU Member States, the right to vote and to be elected in elections to European Parliament, the right to enjoy protection by available diplomatic authorities of Member States in the third countries, and the

\footnotetext{
15 A People's Europe, op. cit., note 5, p. 5.

16 Ibid., pp. 18-30.

17 Preamble TEU (Lisbon), p. 16.

18 See: Articles 9-12 TEU (Lisbon).

19 See: Articles $18-25$ TFEU (Lisbon).

20 Article 9 TEU (Lisbon).
} 
right to address the EU institutions. ${ }^{21}$ In this context it is necessary to add that these rights have been further reconfirmed between Articles 39 and 46 CFREU. ${ }^{22}$ Likewise, it should also be signified that in the Declaration no. 52 TFEU, most of the EU Member States have expressed their attachment to the symbols of the European Union by stating "that the flag with a circle of twelve golden stars on a blue background, the anthem based on the "Ode to Joy" from the Ninth Symphony by Ludwig van Beethoven, the motto "United in diversity", the euro as the currency of the European Union and Europe Day on 9 May will for them continue as symbols to express the sense of community of the people in the European Union and their allegiance to it." ${ }^{23}$

Finally, according to this overview it can be emphasized that since the early stages of the European integration process the EU institutions have been gradually developing and promoting its official ideas aimed at bringing its citizens closer to the Union through various policy fields and numerous initiatives that relay upon the above mentioned documents. In view of that, it can also be asserted that one of the most tangible tools to eventually reach this aim refers to articulation of European citizenship as a concept which adds certain component of identification with the EU to Member States nationals, and therefore can be closely related with the notion of European identity. Nevertheless, to assess as well as to broaden presented overview of the official EU stands regarding the conceptualization of the European identity, it is necessary in the following subchapter to reflect upon several conceptual considerations on the given subject provided by selected authors.

\subsection{European identity according to relevant authors}

Due to various conceptual approaches aimed at articulating European identity, it is necessary to narrow down the focus on a given subject by relying on particular conceptualizations deriving mostly from the field of social sciences. For this reason it seems appropriate to firstly reflect upon specific views on the phenomena of European identity approached from the perspective of Social Constructivism, since, by looking through its conceptual lenses it is possible to grasp some of the main contours which are shaping the ongoing debate about this contested concept. In this regard valuable insights are provided by Risse who in his articulation of social construction of European identity criticizes essentialist approaches to collective identities. In other words, by relying upon the idea that human everyday interactions constitute what Berger and Luckmann (1966) articulated as "the

\footnotetext{
$21 \quad$ Article 20 TEU (Lisbon).

22 See: Articles 39-46 CFREU (Lisbon).

23 Declarations by Member States, 52. Declaration, TFEU (Lisbon), p. 202.
} 
social construction of reality", Risse further explains that "the social environment in which we find ourselves, defines (constitutes) who we are, our identities as social beings". ${ }^{24}$ Therefore, from the perspective of Social Constructivism Risse approaches the contested nature of the European identity by arguing on empirical grounds that "individuals hold multiple social identities", and for that reason "people can feel a sense of belonging to Europe, their nation state, their gender, and so forth". ${ }^{25}$ According to these arguments he signifies that "there might be much more 'Europeanness' enshrined in national culture and, hence, a much stronger collective European identity than is usually assumed." ${ }^{26}$

Consequently, to articulate complementary relationship between European and national identities, Risse explains that multiple identities may mutually correspond in following ways: firstly, as a nested or layered identities (e.g. local, national and European identities), secondly, as a cross-cutting identities (e.g. some group members may belong to another identity group), and finally as a "marble cake" model of multiple identities (e.g. different identity components of individuals may be mutually intertwined in various ways). ${ }^{27}$ Moreover, in order to clarify what identification with Europe and the EU means, he indicates that "different groups might fill it with different content" such is the case of diverse meanings attached to Europe by the French, German and British political elites. ${ }^{28}$ Likewise, by pointing that meanings attached to Europe, the EU and the European identity by the EU institutions and European elites include "the values of modernity and enlightenment", he clarifies that "modern and post-national values have become constitutive for the EU." ${ }^{29}$ Nevertheless, Risse also stresses that as an opposition to this official viewpoint of Europe and European identity stands the conceptualization of "fortress Europe", which in general implies that "Europe and the EU are constructed as exclusionary entities". ${ }^{30}$

Although according to given constructivist perspective it has been clarified that European identity can be perceived as part of multiple identities which are mutually inclusive and not exclusive, as well as it is explained from the same standpoint that identification with the EU and its Member States can be viewed in various forms of complementarity, still, it is needed to provide wider conceptual explana-

\footnotetext{
24 Risse, T., Social Constructivism and European Integration. In: Diez, T.; Wiener, A. (eds.), European Integration Theory, pp. 144-160, 2nd Edition, Oxford University Press, 2009, pp. 145-146.

25 Ibid., p. 151.

26 Ibid., p. 152.

27 Ibid., pp. 152-153.

28 Ibid., p. 153.

29 Ibid., pp. 153-154.

$30 \quad$ Ibid., p. 154.
} 
tions on the given subject to further indicate why, how and in what possible forms is European identity emerging. In this regard corresponding views are provided by Delanty and Rumford who in order to define European identity firstly recognize four important aspects of identity. Namely, first of these aspects refers to constructed nature of identity which derives from social actions, whereas, second aspect refers to its narrative dimension. Furthermore, third aspect refers to relational aspect of identity between self and other, and finally, fourth aspect refers to multiple aspect of collective identity. ${ }^{31}$ In line with these considerations same authors are criticizing the idea of "superior European identity" which would be in tension with national identities by arguing that "to varying degrees, all national identities in Europe contain elements of a European identity, which is not an identity that exists beyond or outside national identities." ${ }^{2}$

Furthermore, they differentiate between personal and collective variants of European identity emphasizing that "proliferation of Europeanized personal identities does not produce a European collective identity as such". ${ }^{33}$ Therefore they assert that collective identity emerges "from a distinctive social group or institutional framework" which is apparently lacking in the case of collective European identity promoted by the EU. ${ }^{34}$ However, they further explain that behind efforts to create such an official collective identity by the EU stands its "legitimating function", which is vaguely indicated in Maastricht Treaty, but more explicitly expressed recently through "symbols of Europeanness", that is, through mechanisms similar to those once used for creation of national identities such as "an emerging EU cultural policy, the euro currency, a passport, and scientific and educational policies aimed at enhancing a consciousness of Europe." ${ }^{35}$ Nonetheless, although Delanty and Rumford are questioning the ability of the EU to foster collective identity similar to national, they are stressing "that the EU is having an impact on personal identities." ${ }^{6}$ Yet, beyond personal and the EU's visions of European identity, same authors are also distinguishing "wider European cultural identity", which is actually referring to "identities in the plural, such as national, regional, political, etc. that are defined by an orientation to a broad cultural conception of Europe." ${ }^{37}$ Finally, in line with these thoughts, Delanty and Rumford provide

\footnotetext{
31 Delanty, G.; Rumford, C., Rethinking Europe: Social Theory and the Implications of Europeanization, London: Routledge, 2005, pp. 51-52.

32 Ibid., p. 54.

33 Ibid.

34 Ibid.

$35 \quad$ Ibid., p. 55.

36 Ibid.

37 Ibid.
} 
conceptualization of European identity which can be perceived "as a cosmopolitan identity embodied in the cultural models of a societal or civilizational identity rather than as a supra-national identity or an official EU identity that is in tension with national identities." 38

As complementary to these conceptualizations, it is also important to emphasize some of the main ideas regarding European identity articulated by Castells in the broader context of his approach to the European Union as a network state. ${ }^{39}$ More precisely, besides brothering previous insights, in this way some explanations will be specified regarding the importance of the European identity for the persistence of the EU project. Therefore, along his general considerations aimed at characterizing the EU in the context of globalization and Information Age as a network state which builds legitimacy on "the ability of its institutions to link up with subnational levels of government", Castells is also emphasizing that "Europe will only unify, at various degrees and under forms yet to emerge, if its citizens want it." ${ }^{40}$ In this regard Castells is reasoning that European identity is necessary for the endurance of the European unification, but at the same time he is questioning its challenging conceptual nature by arguing that such identity cannot be achieved around Christianity, democracy, ethnicity, national identity or around European economic identity. ${ }^{41}$

Nevertheless, despite recognizing a fact that "there is no European identity" Castells still considers that such identity is possible and "it could be built, not in contradiction, but complementarity to national, regional, and local identities". ${ }^{42}$ In other words, he suggests that that European identity could be socially constructed "as project identity; that is, a blue print of social values and institutional goals that appeal to a majority of citizens without excluding anybody, in principle." ${ }^{43}$ In line with these thoughts Castells is optimistically asserting that according to his views "there are embryos of a European project identity" and concludes that "only if these embryos find political expression will the process of European unification ultimately be accomplished." ${ }^{4} 4$

\footnotetext{
$38 \quad$ Ibid., p. 56.

39 Castells, M., The Information Age: Economy, Society and Culture. Volume 3, Second edition, End of Millennium: Wiley-Blackwell, 2010, pp. 365-368.

$40 \quad$ Ibid., p. 367, p. 368.

41 Ibid., pp. 368-369.

42 Ibid., p. 369.

43 Ibid., p. 369.

44 Ibid., p. 369-
} 
To conclude this conceptual overview which so far illustrates various, but affirmatively inclined corresponding insights about why, how and in what forms European identity is or could be envisioned, it is also needed to complement these views with more critical standpoints regarding the same subject. In this regard it is important to refer to several critical concerns about the EU's approaches in the cultural field directed towards the European identity building process by Shore who, from anthropological point of view, emphasizes that the EU lacks common culture and for that reason "there is no popular 'European consciousness' to rival that of the nation-state or lend support to those economic and legal foundations." ${ }^{55}$ In the same context Shore recognizes that legitimacy represents the biggest problem to European integration because "the 'European public', or demos, barely exists as a recognizable category." 46 Therefore, since the success of the Single market and the EU in general depends on the ability of its institutions to foster collective sense of "Europeanness", Shore recognizes how for that reason, since the 1980s, the EU institutions have intensified their involvement in the field of its vaguely defined "cultural sector", which in addition to arts, heritage and media also encompasses areas such as information, tourism, education and sports. ${ }^{47}$

Moreover, besides growing commercial aspect of "culture" under the EU's legal framework, the main reason behind this involvement lies also in a fact that "notion of culture itself is now recognized as a key dimension of European integration." ${ }^{48}$ So, since "European idea" promoted by the EU representatives implies "identity-formation" as well as "culture building", Shore is providing answers to self-posed questions regarding "how is this new Europe being imagined, and whose images prevails?" by analysis of what he ascribes as the "agents of European consciousness". ${ }^{49}$ More precisely, according to Shore this term refers to "all those actors, actions, artefacts, bodies, institutions, policies and representations which, singularly or collectively, help to engender awareness and promote acceptance of the 'European idea." ${ }^{50}$ Thus, Shore argues that these elements "all contribute to creating the conceptual and symbolic foundations that make it possible to imagine the new Europe as a political entity and community, and conceive of oneself as part of that community." ${ }^{1}$ In this regard Shore concludes that purpose of "Eu-

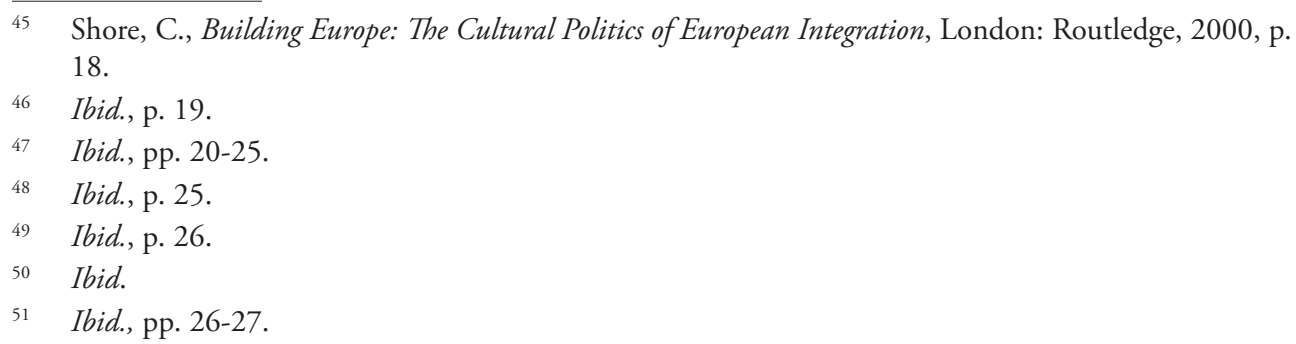


ropeanisation" apparently is "to reconfigure not only the map of Europe but the terms and processes by which people in Europe perceive themselves and construct their identities." ${ }^{2}$

\section{ASSESSING THE EXTENT TO WHICH EUROPEAN CITIZENS AFFILIATE WITH THE EU AT TIMES OF CORONAVIRUS PANDEMIC: REVIEW OF RECENT EUROBAROMETER SURVEYS}

With the aim of assessing the extent to which the EU citizens are currently affiliating with the European Union, especially with regard to the response of the EU to confront the Coronavirus pandemic, it is adequate to rely upon recent Eurobarometer surveys conducted during the 2020. In addition, it is needed to notice that, since these surveys are requested by the European Commission, this also indicates that up-to-date reflections about the level of affiliation of the European citizens to the Union are of great importance to the EU institutions. Nevertheless, what follows is concise review and analysis of certain aspects covered by specifically designed Eurobarometer surveys carried out recently with purpose to provide insights about the European Union Citizenship and Democracy ${ }^{53}$ and the Future of Europe $e^{54}$.

Therefore, although survey on European Union Citizenship and Democracy was conducted at the beginning of Coronavirus pandemic in Europe (i.e. in FebruaryMarch 2020), still, it offers fairly up-to-date findings about the extent to which Member States nationals are aware of their EU citizenship by offering insight regarding several corresponding areas. Specifically, these areas in general explore the awareness, attitudes and opinions of the respondents on the following issues: their EU citizenship status, their EU citizenship rights, their views on free movement within the EU and available benefits while staying in a non-EU countries, their electoral rights when residing in other EU countries, and finally, their views on the measures which could increase the turnout in European elections. ${ }^{55}$ Accordingly, some of the key findings of this survey in general indicate that majority of respondents (91\%) are highly familiar with the term "citizen of the European Union" as well as on average they are also highly aware of certain EU citizens' rights (81\%). ${ }^{56}$

\footnotetext{
$52 \quad$ Ibid., p. 27.

53 Flash Eurobarometer 485, European Union Citizenship and Democracy, Summary, Fieldwork: February-March 2020, Kantar, European Union, 2020 (Flash Eurobarometer 485).

54 Special Eurobarometer 500, Future of Europe, First Results, Fieldwork: October-November 2020, Kantar, European Union, 2021 (Special Eurobarometer 500).

55 Flash Eurobarometer 485, op. cit., note 53, pp. 1-3.

56 Ibid., p. 5.
} 
Moreover, majority of respondents (84\%) think that the economy of their countries benefits from the free movement of the EU citizens, and likewise they are mostly $(71 \%)$ aware of their electoral rights at European, national, regional and municipal levels. ${ }^{57}$ Furthermore, for majority of respondents $(63 \%)$ it is justifiable that EU citizens who are living in the EU country other than their own may vote on national elections and referendums in their country of residence. ${ }^{58}$ Finally, regarding the views of respondents about the measures which could increase the turnout in the next European Parliament elections, most of them expressed greater willingness to vote if more information was provided about both, the effects of the EU on their lives and programs of candidate parties (both 79\%). ${ }^{59}$

Apparently, despite the fact that this survey reflects certain stands of the Member States nationals prior to Coronavirus pandemic, yet, it indicates that in contemporary moment respondents are to a large extent aware of their European citizenship status, rights and benefits. Moreover, results of this survey also provide insights about respondents' views on actions which, if applied, could potentially increase their political participation at the EU level, and therefore increase their affiliation with the EU.

However, in order to more closely assess the extent to which the EU citizens are affiliating with the Union with regard to the response of the EU to confront the Coronavirus pandemic, it is necessary to complement previous insights with recent survey on the Future of Europe. In this regard it is needed to signify that this survey was carried out during the second wave of the Coronavirus pandemic in Europe (i.e. in October - November 2020), and for that reason sheds more light on the current stands and perceptions of the EU citizens regarding the EU in general, and its role in confronting the Coronavirus pandemic in particular. Apparently, this survey accentuates contemporary views of European citizens about the future of Europe as its central issue, but it also explicitly explores their contemporary views regarding the EU's response to the Coronavirus pandemic. More precisely, areas covered by this survey examine respondents' views on the following issues: their attitudes towards the EU, their ability to be heard at the EU level, their opinions about the Conference on the future of Europe, their views on the future of Europe, and finally, their stands regarding the approach of the EU to confront the Coronavirus pandemic. ${ }^{60}$ Nonetheless, due to limited framework of this paper and its thematic context, it is adequate just to refer to certain findings

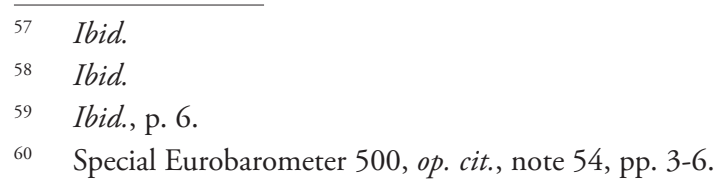


which correspond to major questions of this paper within selected issues covered by this survey. Therefore, some of the findings in the context of exploring the attitudes of the EU citizens towards the EU indicate that almost half of respondents have positive image of the EU (47\%), whereas a significant number of them views the EU neutrally (39\%) and minority negatively (14\%). ${ }^{61}$ However, it is significant to notice that in regard to perceived evolution of the EU's image in the period over the past six month - which refers to period during the pandemic which took place approximately between May and October 2020 - most respondents haven't changed their image of the EU (60\%), although some did in both negative (26\%) and positive $(13 \%)$ direction. ${ }^{62}$ Also, most of the respondents $(60 \%)$ confirmed that the Coronavirus pandemic made them reflect on the future of the EU. ${ }^{63}$

Likewise, it is noticeable that Coronavirus pandemic have made recognizable impact on respondents' viewpoints regarding the future of Europe. In other words, findings indicate that as a main EU's assets respondents rank the respect for democracy, human rights and the rule of law (32\%), and then its economic, industrial and trading power (30\%). But also, besides valuing the standard of living of the EU citizens (23\%), it is significant to notice that respondents consider the good relationship and solidarity between the EU's Member States (23\%) to be on top of the most important assets of the EU. ${ }^{64}$ Furthermore, it is as well noteworthy that along with challenges such as climate change (45\%), terrorism (38\%) and forced migration and displacement (27\%), respondents also view health-related risks $(37 \%)$ as one of the main challenges for the future of the EU. ${ }^{65}$ Moreover, it is interesting to indicate that besides comparable living standards (35\%), among the most helpful developments for the future of Europe respondents view stronger solidarity among Member States (30\%) as well as development of a common health policy $(25 \%) .{ }^{66}$ Also, among respondents' explicit views regarding the approach of the EU to confront the Coronavirus pandemic, findings indicate that in their opinion the EU should prioritize the development of European health policy (32\%), as well as it should increase investments for treatments and vaccinations (30\%) and develop a European strategy in order to be able to face a similar crisis in the future (26\%) ${ }^{67}$ Lastly, in regard to the EU's financial response to the Coronavirus pandemic respondents mostly consider it to be effective, which in

\footnotetext{
61 Ibid., 9-10.

${ }^{62} \quad$ Ibid., p. 11.

63 Ibid., p. 12.

${ }^{64}$ Ibid., p. 26.

65 Ibid., p. 28.

66 Ibid., p. 30.

67 Ibid., p. 33.
} 
particular refers to their views on the effectiveness of the EU's financial support to keep people in jobs (74\%), including public subsidies to companies facing difficulties (72\%) as well as the "Next Generation EU" recovery plan (68\%), and the effectiveness of allowing national governments to make public deficit to support the economy $(67 \%){ }^{68}$

In general, according to these findings it can be emphasized that Coronavirus pandemic had significant impact on respondents' views regarding the EU and its future. Specifically, this is evident by observing the facts which imply that respondents have ranked the good relationship and solidarity between the EU's Member States among the most important EU's assets, as well as they view health-related risks as one of the main challenges for the future of the EU. Moreover, the impact of Coronavirus pandemic is further evident by respondents' attitudes which indicate that stronger solidarity among Member States and prioritization of the development of common health policy are to be considered among the most helpful developments for the future of Europe. Lastly, it can be argued that according to views of respondents - which indicate that the EU should prioritize the development of its common health policy, increase investments for treatments/vaccinations, and establish a common strategy to face similar crisis in the future - all point to certain aspects, which have potential if applied successfully with existing financial supports, to rise the affiliation of the European citizens towards the EU in and after the Coronavirus pandemic.

\section{APPROACHING SOLIDARITY ACTIONS OF THE EU AND ITS CITIZENS TO CONFRONT THE CORONAVIRUS CRISIS AS INSTRUMENTS THAT FOSTER EUROPEAN UNITY}

\subsection{The response of the EU to confront the Coronavirus crisis through solidarity actions}

With the aim to provide insights about solidarity actions directed to confront the Coronavirus crisis by the EU institutions, firstly it is needed to indicate solidarity dimension of such major initiatives, and then, to identify other, more informal EU's solidarity actions which transcend mere financial support, and for that reason can be viewed as instruments that are explicitly or implicitly enhancing a sense of cohesion and unity among the European citizens. Therefore, it is important to signify that the EU institutions have reacted promptly (i.e. 30 March 2020) to the outbreak of the Coronavirus by amending existing provisions of the EU Solidarity Fund in order to provide urgent assistance to Member States facing not

68 Ibid., p. 35. 
just natural disasters, but also major public health emergencies. More precisely, according to its competences and in line with the principle of subsidiarity, the EU institutions have expressed their motivation to do so by amending Regulation (EU) 2020/461 in the following words: "In the event of major public health emergencies, the Union should show its solidarity with Member States and the population concerned by providing financial assistance to help the population affected, to contribute to a rapid return to normal living conditions in the affected regions and to contain the spreading of infectious diseases." ${ }^{69}$

However, the most evident and exceptional response of the EU institutions to confront the Coronavirus pandemic is reflected in the overall composition of its new long-term budget for the period 2021-2027, which together with its recovery instrument amounts EUR 1.8 trillion. Namely, adopted in December 2020, the EU's new Multiannual financial framework (2021-2027) $)^{70}$ amounts EUR 1.074 trillion, whereas its Recovery Instrument (i.e. "Next Generation EU”) ${ }^{71}$ amounts EUR 750 billion. In this regard, and due to limited format of this paper, it is adequate just to emphasize that, in general, both instruments contain specifically designed solidarity measures which are aiming to "help repair the economic and social damage caused by the coronavirus pandemic and steer the transition towards a modern, sustainable and resilient Europe. ${ }^{\prime 2}$ Nevertheless, since the purpose of the EU's Recovery Instrument is explicitly directed to face the Coronavirus crisis, it is noteworthy that one of its aims signifies integrative dimension of this initiative by supporting "measures in the form of reforms and investments to reinvigorate the potential for sustainable growth and employment in order to strengthen cohesion among Member States and increase their resilience. ${ }^{73}$

Moreover, besides mentioned formal actions directed to tackle the Coronavirus pandemic which inevitably contain solidarity dimension, the EU institutions have also initiated, supported or promoted various informal solidarity actions which can be viewed as instruments that enhance cohesion and unity among the EU

69 Regulation (EU) 2020/461 of the European Parliament and of the Council of 30 March 2020 amending Council Regulation (EC) No 2012/2002 in order to provide financial assistance to Member States and to countries negotiating their accession to the Union that are seriously affected by a major public health emergency (OJ L 99, 31.3.2020, p. 9-12), preamble.

70 Council Regulation (EU, Euratom) 2020/2093 of 17 December 2020 laying down the multiannual financial framework for the years 2021 to 2027 (OJ L 433I, 22.12.2020, pp. 11-22).

71 Council Regulation (EU) 2020/2094 of 14 December 2020 establishing a European Union Recovery Instrument to support the recovery in the aftermath of the COVID-19 crisis (OJ L 433I, 22.12.2020, pp. 23-27) (Council Regulation (EU) 2020/2094).

72 The EU's 2021-2027 long-term Budget and NextGenerationEU: Facts and figures, European Union, 2021, p. 6.

73 Council Regulation (EU) 2020/2094, art 1. 
citizens. In view of that, it is suitable to refer to the webpages within the official website of the European Union (i.e. Europa.eu) as a source which contains relevant information about the common EU response to COVID-19. ${ }^{74}$ In this context, among the available information on the given subject at this web source, it is relevant to concisely reflect upon the provided materials complied under the online initiative titled "European solidarity in action", which, in general, points users to various activities, testimonials and stories of European solidarity provided by the subsequent webpages of the European Parliament (i.e. webpage \#EuropeansAgainstCovid19), the European Commission (i.e. webpage Coronavirus: European Solidarity in action) and the European Council along with the Council of the EU (i.e. webpage European Solidarity in action: Europeans vs COVID-19).

Therefore, on the indicated webpage of the European Parliament users can get insights about numerous stories of European solidarity across the Member States, as well as they can get involved personally in sharing and promoting similar cases by the initiative \#EuropeansAgainstCovid19. In this regard, it is worth noticing that this webpage also contains narratives that promote common actions in facing the Coronavirus crisis such as: "It's not in division that we move forward, it's in togetherness". ${ }^{75}$ Likewise, previously specified webpage of the European Commission presents various solidarity actions taken by the EU institutions, its Member States, citizens and companies to face the Coronavirus crisis by indicative examples of European solidarity in treating patients, protecting health workers and citizens, bringing people home and supporting asylum seekers. In view of that, among these initiatives it is as well significant to point at the European Solidarity Tracker - an interactive application that offers to users a visual representation of solidarity interactions among the EU Member States and the EU institutions. ${ }^{76}$ In a similar way, it can also be noticed that mentioned webpage of the European Council and the Council of the EU contains unifying narratives reflected in syntaxes such as "Europeans vs COVID-19" and "We stand together" - used for titles of the webpage content. Correspondingly, this webpage also presents to users various examples of European solidarity in treating patients, sharing medical supplies and bringing EU citizens home, as well as it provides examples of the Member States supporting one another during the Coronavirus crisis. ${ }^{77}$

74 Europa.eu. The common EU response to COVID-19, [https://europa.eu/european-union/coronavirus-response_en], Accessed 9April 2021.

75 Europarl.europa.eu. \#EuropeansAgainstCovid19, [https://www.europarl.europa.eu/europeans-against-covid19/en/], Accessed 9April 2021.

76 Ec.europa.eu. Coronavirus: European Solidarity in action, [https://ec.europa.eu/info/live-work-traveleu/coronavirus-response/coronavirus-european-solidarity-action_en], 9 Accessed April 2021.

77 Consilium.europa.eu. European Solidarity in action. Europeans vs COVID-19, [https://www.consilium. europa.eu/en/policies/coronavirus/european-solidarity-in-action/], Accessed 9 April 2021. 
Lastly, although it can be emphasized that this overview illustrates that the EU's response to the Coronavirus crisis, through its both formal and informal initiatives, has solidarity dimension which can enhance a sense of cohesion and unity among the European citizens, still, the reach and effectiveness of these actions remains questionable. With this in mind, it seems suitable to conclude this subchapter - and to pave the way for the following one - by pointing at the important role of civil society in recovery of Europe. Namely, this will be portrayed by briefly referring to Resolution adopted by the European Economic and Social Committee (EESC) in June 2020 which holds the following formal title, but also explicitly descriptive and suggestive subtitle that resonate evident integrative dimension: Resolution on "EESC proposals for post-COVID-19 crisis reconstruction and recovery: "The EU must be guided by the principle of being considered a community of common destiny'" ${ }^{78}$ In this regard, since the EESC as an official consultative body of the EU represents - among various economic and social interest groups also, the civil society organizations at the EU level, ${ }^{79}$ it is noteworthy that in the introductory part of specified Resolution it is stated that "The participation of all citizens, through the organizations of the social partners and of civil society, will make the process of reforming the economy and society possible. The Member States and the EU must therefore ensure that in this complex process no one is left behind." 80

\subsection{The response of representative CSOs active in the field of promoting European citizenship to confront the Coronavirus crisis through solidarity actions}

Since it was previously indicated that the EU's response to the Coronavirus crisis has solidarity dimension which can enhance cohesion and unity among the EU citizens, it is also necessary to complement these considerations with insights about the same matter beyond the EU institutions, that is, from the perspective of civil society organizations (CSOs) active in promotion of European citizenship. Therefore, in order to do so, first it will be needed to present representative CSOs in the context of the subject matter, and then, to provide a concise review of their solidarity actions which can be viewed as instruments that, from horizon-

78 Resolution on 'EESC proposals for post-COVID-19 crisis reconstruction and recovery: "The EU must be guided by the principle of being considered a community of common destiny." based on the work of the Subcommittee on post-COVID-19 recovery and reconstruction, OJ C 311, 18.9.2020, p. 1-18 (Resolution on 'EESC proposals for post-COVID-19 crisis reconstruction and recovery).

79 Eesc.europa.eu. European Economic and Social Committee, About, [https://www.eesc.europa.eu/en/ about], Accessed 12 April 2021.

80 Resolution on 'EESC proposals for post-COVID-19 crisis reconstruction and recovery, op. cit., note 78 , p. 2. 
tal perspective of governance, foster cohesion and unity among the EU citizens. However, prior to do that it is important to stress that from the perspective of the EU institutions civil society plays important role for the European integration process, which has been clearly signified within the Article 11 of the Treaty of Lisbon (i.e. consolidated version of TEU) in the following words: "The institutions shall maintain an open, transparent and regular dialogue with representative associations and civil society." ${ }^{81}$ Thus, in view of the fact that there are numerous CSOs active at the EU level, it is necessary to provide exemplary insights about the CSOs which are promoting engagement of European citizens at the EU level. In this regard, relevant CSOs which will be presented, along with their actions in response to the Coronavirus crisis, are the Civil Society Europe (CSE), the European Citizen Action Service (ECAS) and The European Civic Forum (ECF).

Accordingly, the Civil Society Europe (CSE) was established in 2014 as a result of cooperation between organizations involved in the European Year of Citizens, and as such it encompasses 28 European CSO networks which are "working towards regenerating the European project around the shared values of Equality, Solidarity, Inclusiveness and Democracy." ${ }^{22}$ Also, the CSE is pursuing its aims through partnerships, campaigns, events, projects, publications and its working groups. Nevertheless, the CSE reacted promptly (i.e. April 16 2020) to the Coronavirus crisis by organizing an online campaign titled "Covid 19: Civil society at the forefront" by collecting and presenting through its webpages numerous initiatives made by the European CSOs to confront the Coronavirus crisis. In other words, these initiatives are organized within the categories which are representing available resources, actions and appeals as responses of the CSE members and their partners to the pandemic. ${ }^{83}$ In this regard, it is important to note that besides representing a valuable resource on the subject matter, this campaign also indicates that there are numerous CSOs which are currently active at the EU level, as well as it shows that during the Coronavirus crisis they are mutually cooperating or individually providing solidarity initiatives concerning European CSOs in general, and European citizens in particular. Moreover, in regard to its response to the Coronavirus crisis the CSE also reacted with an open letter to the EU institutions a day before the meeting of the European Council (i.e. June 19 2020) which discussed the new EU's budget and its recovery plan. The aim of this letter, cosigned by $52 \mathrm{CSO}$ platforms, was therefore to stress the position and expectations of the European

\footnotetext{
$81 \quad$ Article 11 TEU (Lisbon).

82 Civilsocietyeurope.eu. Civil Society Europe - European coordination of civil society organizations, [https:// civilsocietyeurope.eu/], Accessed 13 April 2021.

83 Civilsocietyeurope.eu. Covid 19: Civil society at the forefront, [https://civilsocietyeurope.eu/covid-19-civil-society-at-the-forefront/], Accessed 13April 2021.
} 
civil society in the context of this meeting. However, it is notable that among the appeals stressed in this letter, it was also pointed that funding within the area of Cohesion and Values of the new EU's budget "should be targeted to benefit civil society organizations which work to promote and realize EU values at national and local level, supporting their work beyond short-term project grants." ${ }^{84}$

Next relevant CSO on the subject matter is the European Citizen Action Service (ECAS), which is for almost 30 years active in the field of promoting EU rights and European democracy with mission to "empower citizens in order to create a more inclusive and stronger European Union." ${ }^{85}$ Also, the ECAS is aiming to achieve its goals through various initiatives, projects, publications, partnerships and trainings. In the context of its response to Coronavirus crisis, it is noteworthy that in January 2021 ECAS has published a study titled "Under a Double Lockdown: The Impact of the COVID-19 Pandemic on Mobile EU Citizens' Rights". In general, this study provides valuable insight about the effects of the pandemic on one of the most important EU rights - the freedom of movement. Moreover, the study also resulted in articulation of recommendations on the subject matter appointed towards the EU institutions ${ }^{86}$ Furthermore, in January 2021 the ECAS organized online Conference dealing with the current issues of the free movement titled "State of the Union Citizens' Rights 2021: Moving Together Beyond the Pandemic". ${ }^{87}$ In addition, it is as well important to point at particular ECAS's service that was available before the pandemic, but which gained importance due to the its outbreak. Namely, this refers to a free online service titled "Your Europe Advice" which purpose is to offer legal advices regarding personal EU rights to European citizens by the experts in both the EU and national laws. ${ }^{88}$

Finally, the last representative CSO is the European Civic Forum (ECF), a panEuropean network established in 2005 which encompasses more than 110 organizations in 29 European countries. In general, the ECF "connects civic actors, institutions, academics and media through conferences, forums, alliances, and

84 Civilsocietyeurope.eu. EU institutions repond to our letter on Europe's recovery after the pandemic and civil society, [https://civilsocietyeurope.eu/eu-institutions-repond-to-our-letter-on-europes-recovery-after-the-pandemic-and-civil-society/], Accessed 13April 2021.

85 Ecas.org. European Citizen Action Service, [https://ecas.org/], Accessed 13 April 2021.

86 Ecas.org. ECAS Publications, Under a Double Lockdown: The Impact of the COVID-19 Pandemic on Mobile EU Citizens' Rights, [https://ecas.org/under-a-double-lockdown/], Accessed 13April 2021.

87 Ecas.org. ECAS Publications, Key Messages from the 'State of the Union Citizens' Rights 2021: Moving Together Beyond the Pandemic' Conference, [https://ecas.org/key-messages-from-the-state-of-the-unioncitizens-rights-2021-moving-together-beyond-the-pandemic-conference/], Accessed 13 April 2021.

88 Ecas.org. Your Europe Advice (YEA), [https://ecas.org/services/your-europe-advice-yea/], Accessed April 132021 ; Civilsocietyeurope.eu. Covid 19: Civil society at the forefront, [https://civilsocietyeurope.eu/ covid-19-civil-society-at-the-forefront/], Accessed 13 April 2021. 
campaigns, thus fostering a transnational expression of citizenship, Europeanizing civic participation." ${ }^{89}$ Therefore, in a view of the Coronavirus outbreak the ECF also reacted promptly (i.e. 10 April 2020) by sending an open letter (cosigned by numerous European CSOs) to representatives of the EU institutions, with an aim to seek support and to address their major concerns at the EU level regarding the position of the CSOs in the current situation. ${ }^{90}$ Moreover, the ECF have also launched an online campaign titled "Solidarity amid COVID - 19 crises" (available at their official webpages), through which they have mapped and made visible a numerous solidarity initiatives coming from CSOs, citizens or businesses across Europe. In the framework of this initiative the ECF have also published a position paper titled "The future must be different from the past" in which they have drafted a "ten lessons learned out of the crisis, for wide discussion" ${ }^{91}$ At last, in the context of the overall approach of the ECF to the Coronavirus crisis it is noteworthy to refer to a statement titled "At a distance, united as never before" written by the president of the ECF to its member at the very beginning of the pandemic in Europe (i.e. 16 March 2020). Namely, in this statement among other highlighted points it is also underlined that "We want the EU to be a major actor to organize solidarity in the crisis" as well as it is accentuated that "The crisis tests European claimed values: let's pass this test successfully" ${ }^{22}$ Clearly, this narrative signifies a need for common actions to be taken to overcome the Coronavirus crisis in Europe. Moreover, according to presented views these actions should be taken at the European level and by the EU, as well as in accordance with European values.

On the whole, provided insights about the solidarity actions of the representative CSOs to confront the Coronavirus crisis complement previously presented EU's actions. Likewise, they as well indicate that particular representatives of European citizens are approaching the Coronavirus crisis not just as a threat, but also as a chance to enhance cooperation, influence policy-makers and provide assistance to other CSOs and European citizens at the EU level. For that reason, presented reviews of solidarity actions directed to confront the Coronavirus crisis of both, the EU institutions and representative CSOs, can be viewed as complementary instruments that foster cohesion and unity among the EU citizens.

89 Civic-forum.eu. European Civic Forum, [https://civic-forum.eu/], Accessed 13 April 2021.

${ }_{90}$ Civic-forum.eu. Open letter to Ms von der Leyen, Ms Jourova and Mr Reynders: CSOS must be able to act in response to social emergencies, [https://civic-forum.eu/publications/open-letter/national-platforms-call-eu-commission], Accessed 13 April 2021.

${ }_{91}$ Civic-forum.eu. The future must be different from the past, Ten lessons learned out of the crisis, for wide discussion, [https://civic-forum.eu/position/lessons-learned-from-covid-19-crisis], Accessed 13nApril 2021.

92 Civic-forum.eu. At a distance, united as never before, [http://civic-forum.eu/press-release/at-a-distanceunited-as-never-before], Accessed 13 April 2021. 


\section{CONCLUSION}

The main aim of this paper was to assess the potential of the EU and its citizens to face the Coronavirus pandemic as a chance to reaffirm the European identity. To achieve this aim qualitative methodology was applied to provide a review and analysis of the responses directed to meet the challenges of Coronavirus crisis by the EU institutions and the CSOs active in the field of promoting European citizenship. As a result of that, the key findings of this inquiry indicate that analyzed initiatives contain solidarity dimension, and therefore, have potential to reaffirm the European identity, that is, to enhance cohesion and unity among the EU citizens.

Accordingly, in this paper it was indicated that evolving approaches of the EU institutions aimed at bringing European citizens closer to the Union have found its articulation in European citizenship - a concept which fosters identification with the European Union and for that reason is closely related with the notion of the European identity. However, broader conceptualizations of European identity (or identities), beyond the official EU's views, indicate a contested nature of this concept, which in general refers to variety of possible ways of belonging to the EU and Europe, none of which is in tension with national identities. Nevertheless, since the prospect of the EU project depends on the consent of the Member States nationals - who are simultaneously the EU citizens - it is not surprising that occurrence of the Coronavirus pandemic and initial discords of the EU leaders on how to deal with it, have been regarded by many as a great test of persistence for the Union. For this reason, reviewed recent Eurobarometer surveys provide valuable insights. More precisely, they indicate that the Coronavirus pandemic had significant impact on respondents' views regarding the EU and its future. Still, they are also pointing to a potential of the EU institutions to bring their citizens closer to the Union in and after the Coronavirus pandemic, if they attain their expectations (e.g. by prioritizing the development of common health policy).

Moreover, provided insights about the solidarity actions of the EU and representative CSOs to confront the Coronavirus crisis suggest that they can be viewed as complementary instruments that foster cohesion and unity among the EU citizens. Likewise, this also suggests that ability to further utilize this potential may have positive impact on the European integration process in and after the pandemic. Nonetheless, the results also reveal that the extent and effectiveness of both, reviewed and future similar initiatives, remains questionable due to still unknown outcomes of the Coronavirus pandemic. In other words, it can be argued that further actions of the EU in handling this pandemic, will be the main source of either beneficial or detrimental effects regarding the level of cohesion and unity 
among the EU citizens. In view of that, it can be expected that European CSOs, and specifically those active in promotion of European citizenship, will continue to influence EU policy-makers to articulate decisions aimed at facing the Coronavirus pandemic in alignment with the European values expressed in the EU Treaties, and which inevitably promote unity in solidarity. In this regard, European CSOs shouldn't merely promote official EU views, but should remain to be constructively critical whenever is necessary.

\section{REFERENCES}

\section{BOOKS AND ARTICLES}

1. Castells, M., The Information Age: Economy, Society and Culture. Volume 3, Second edition, End of Millennium: Wiley-Blackwell, 2010

2. Delanty, G.; Rumford, C., Rethinking Europe: Social Theory and the Implications of Europeanization, London: Routledge, 2005

3. Dorotić, J., Krajobrazne politike i njihova uloga u izgradnji identiteta EU, (Landscape Policies and Their Role in Building the EU Identity) Doctoral thesis, Sveučilište Josipa Jurja Strossmayera u Osijeku, 2019

4. Risse, T., Social Constructivism and European Integration. In: Thomas Diez and Antje Wiener (eds.), European Integration Theory, 2nd Edition, Oxford University Press, 2009, pp. $144-160$

5. Shore, C., Building Europe: The Cultural Politics of European Integration, London, Routledge, 2000

\section{EU LAW}

1. Charter of Fundamental Rights of the European Union (2016), OJ C 202, 7.6.2016.

2. Council Regulation (EU) 2020/2094 of 14 December 2020 establishing a European Union Recovery Instrument to support the recovery in the aftermath of the COVID-19 crisis (OJ L 433I, 22.12.2020, pp. 23-27)

3. Council Regulation (EU, Euratom) 2020/2093 of 17 December 2020 laying down the multiannual financial framework for the years 2021 to 2027 (OJ L 433I, 22.12.2020, pp. 11-22)

4. Regulation (EU) 2020/461 of the European Parliament and of the Council of 30 March 2020 amending Council Regulation (EC) No 2012/2002 in order to provide financial assistance to Member States and to countries negotiating their accession to the Union that are seriously affected by a major public health emergency (OJ L 99, 31.3.2020, p. 9-12)

5. Treaty establishing the European Economic Community. Rome, 25 March 1957.

6. Treaty of Lisbon amending the Treaty on European Union and the Treaty establishing the European Community, signed at Lisbon, 13 December 2007, OJ C 306, 17.12.2007.

7. Treaty on European Union (Consolidated Version 2016), OJ C 202, 7.6.2016. 
8. Treaty on the Functioning of the European Union (Consolidated version 2016), OJ C 202, 7.6.2016.

\section{OFFICIAL EU DOCUMENTS}

1. A People's Europe: Reports from the ad hoc Committee, Bulletin of the European Communities, Supplement 7/85. Luxemburg: Office for Official Publications of the European Communities, 1985

2. Flash Eurobarometer 485, European Union Citizenship and Democracy, Summary, Fieldwork: February-March 2020, Kantar, European Union, 2020

3. Special Eurobarometer 500, Future of Europe, First Results, Fieldwork: October-November 2020, Kantar, European Union, 2021

4. The EU's 2021-2027 long-term Budget and NextGenerationEU: Facts and figures, European Union, 2021

5. Resolution on 'EESC proposals for post-COVID-19 crisis reconstruction and recovery: "The EU must be guided by the principle of being considered a community of common destiny." based on the work of the Subcommittee on post-COVID-19 recovery and reconstruction, OJ C 311, 18.9.2020, p. 1-18

6. Declaration on European Identity, (Copenhagen, 14 December 1973), Bulletin of the European Communities. December 1973, No 12

7. Solemn Declaration on European Union, (Stuttgart, 19 June 1983), Bulletin of the European Communities, No. 6/1983

\section{WEBSITE REFERENCES}

1. Civic-forum.eu. At a distance, united as never before, [http://civic-forum.eu/press-release/ata-distance-united-as-never-before], Accessed 13 April 2021

2. Civic-forum.eu. European Civic Forum, [https://civic-forum.eu/], Accessed 13 April 2021

3. Civic-forum.eu. Open letter to Ms von der Leyen, Ms Jourova and Mr Reynders: CSOS must be able to act in response to social emergencies, [https://civic-forum.eu/publications/open-letter/ national-platforms-call-eu-commission], Accessed 13 April 2021

4. Civic-forum.eu. The future must be different from the past, Ten lessons learned out of the crisis, for wide discussion, [https://civic-forum.eu/position/lessons-learned-from-covid-19-crisis], Accessed 13 April 2021

5. Civilsocietyeurope.eu. Civil Society Europe - European coordination of civil society organizations, [https://civilsocietyeurope.eu/], Accessed 13 April 2021

6. Civilsocietyeurope.eu. Covid 19: Civil society at the forefront, [https://civilsocietyeurope.eu/ covid-19-civil-society-at-the-forefront/], Accessed 13 April 2021

7. Civilsocietyeurope.eu. EU institutions repond to our letter on Europe's recovery after the pandemic and civil society, [https://civilsocietyeurope.eu/eu-institutions-repond-to-our-letteron-europes-recovery-after-the-pandemic-and-civil-society/], Accessed 13 April 2021 
8. Consilium.europa.eu. European Solidarity in action. Europeans vs COVID-19, [https://www. consilium.europa.eu/en/policies/coronavirus/european-solidarity-in-action/], Accessed 9 April 2021

9. Ec.europa.eu. Coronavirus: European Solidarity in action, [https://ec.europa.eu/info/livework-travel-eu/coronavirus-response/coronavirus-european-solidarity-action_en], Accessed 9 April 2021

10. Ecas.org. ECAS Publications, Key Messages from the 'State of the Union Citizens' Rights 2021: Moving Together Beyond the Pandemic' Conference, [https://ecas.org/key-messages-from-thestate-of-the-union-citizens-rights-2021-moving-together-beyond-the-pandemic-conference/], Accessed 13 April 2021

11. Ecas.org. ECAS Publications, Under a Double Lockdown: The Impact of the COVID-19 Pandemic on Mobile EU Citizens' Rights, [https://ecas.org/under-a-double-lockdown/], Accessed 13 April 2021

12. Ecas.org. European Citizen Action Service, [https://ecas.org/], Accessed 13 April 2021

13. Ecas.org. Your Europe Advice (YEA), [https://ecas.org/services/your-europe-advice-yea/], Accessed April 132021 ; Civilsocietyeurope.eu. Covid 19: Civil society at the forefront, [https://civilsocietyeurope.eu/covid-19-civil-society-at-the-forefront/], Accessed 13 April 2021

14. Eesc.europa.eu. European Economic and Social Committee, About, [https://www.eesc.europa. eu/en/about], Accessed 12 April 2021

15. Europa.eu. The common EU response to COVID-19, [https://europa.eu/european-union/ coronavirus-response_en], Accessed 9 April 2021

16. Europarl.europa.eu. \#EuropeansAgainstCovid19, [https://www.europarl.europa.eu/europeans-against-covid19/en/], Accessed 9 April 2021 